\title{
PENGARUH MODIFIKASI STANDAR MAKANAN NON-DIET TERHADAP BIAYA MAKAN YANG TERBUANG PADA PASIEN DI RSUP dr. SOERADJI TIRTONEGORO KLATEN
}

\author{
The Effect of Non-Diet Food Standards Modification on Wasted Food Costs In \\ Geriatric Patients at RSUP dr. Soeradji Tirtonegoro Klaten
}

Mawar Lestari ${ }^{1}$, Friska Citra Agustia ${ }^{2}$, Dika Betaditya ${ }^{3}$

Program Studi Ilmu Gizi Universitas Jenderal Soedirman

\begin{abstract}
Decreasing food intake in geriatric patients due to physical and psychological conditions has an impact on the high percentage of food plate waste and wasted food costs. This study aims to determine the effect of non-diet food standards modification on the cost of food wasted on class III geriatric patients at RSUP dr. Soeradji Tirtonegoro Klaten. This experimental study used a test only with control group design. The sample consisted of 34 people divided into 2 groups, the treatment group that received food standard modification and the control group that received food according to hospital standards. The food plate waste of each group was observed for 2 days using the Comstock visual estimation method. Wasted food costs were calculated by multiplying the percentage of food plate waste per menu item with food prices. The effect of non-diet food standards modification on wasted food costs was analyzed using the Mann Whitney test with a confidence degree of $95 \%(\alpha=0.05)$. The average wasted food cost in the treatment group was Rp 2.806,34 and the control group was $R p$ 3.443,43. The results of the analysis of the effect of non-diet food standards modification on wasted food cost by the Mann Whitney test showed a p-value of 0.109 (> 0.05). There is no significant effect of non-diet food standards modification on wasted food costs in class III geriatric patients at RSUP dr. Soeradji Tirtonegoro Klaten.
\end{abstract}

Keywords: non-diet food standards, geriatric, wasted food costs

\begin{abstract}
ABSTRAK
Penurunan asupan makan pada pasien geriatri akibat kondisi fisik dan psikologis berdampak pada tingginya sisa makanan dan biaya makan yang terbuang. Penelitian ini bertujuan untuk mengetahui pengaruh modifikasi standar makanan non diet terhadap biaya makan yang terbuang pada pasien geriatri kelas III di RSUP dr. Soeradji Tirtonegoro Klaten. Penelitian eksperimental ini menggunakan rancangan post-test only with control group design. Sampel berjumlah 34 orang yang dibagi menjadi 2 kelompok yaitu kelompok perlakuan yang mendapat modifikasi standar makanan dan kelompok kontrol yang mendapat makanan sesuai standar rumah sakit. Masing-masing kelompok diamati sisa makanannya selama 2 hari menggunakan metode taksiran visual Comstock. Biaya makan yang terbuang dihitung dengan mengalikan persentase sisa makanan per item menu dengan harga makanan. Pengaruh modifikasi standar makanan non diet terhadap biaya makan yang terbuang dianalisis menggunakan uji Mann Whitney dengan derajat kepercayaan 95\% $(\alpha=0,05)$. Rata-rata biaya makan yang terbuang pada kelompok perlakuan sebesar Rp 2.806,34 dan kelompok kontrol sebesar Rp 3.443,43. Hasil analisis pengaruh modifikasi standar makanan non diet terhadap biaya makan yang terbuang dengan uji Mann Whitney menunjukkan $p$-value sebesar 0,109 (>0,05) sehingga tidak ada pengaruh modifikasi standar makanan non diet terhadap biaya makan yang terbuang pada pasien geriatri kelas III di RSUP dr. Soeradji Tirtonegoro Klaten.
\end{abstract}

Kata kunci : standar makanan non diet, geriatri, biaya makan terbuang 


\section{PENDAHULUAN}

Pasien geriatri adalah pasien berusia lanjut (diatas 60 tahun) dengan berbagai masalah kesehatan akibat gangguan fungsi jasmani dan rohani maupun kondisi sosial yang bermasalah (PERGEMI, 2017). Kelompok lanjut usia (lansia) termasuk dalam kelompok rawan gizi, memiliki kondisi mudah mengalami malnutrisi dan gangguan kesehatan. Penelitian Lugito et al. (2015) pada pasien geriatri di RS Cipto Mangunkusumo menyatakan bahwa $32,2 \%$ pasien mengalami malnutrisi dan $42,6 \%$ pasien berisiko malnutrisi.

Malnutrisi pada pasien geriatri berkaitan dengan penurunan asupan makan. Menurut Morley (2012) terdapat penurunan asupan makan mencapai $30 \%$ pada pasien laki-laki dan $20 \%$ pada pasien perempuan, serta rata-rata pasien geriatri mengkonsumsi kurang dari 1000 $\mathrm{kkal} / \mathrm{hari}$, sehingga tidak memenuhi kebutuhan energi harian. Hal tersebut dapat disebabkan oleh kondisi fisik dan psikologis yang berdampak pada penurunan nafsu makan (Wellman dan Kamp, 2017). Kebutuhan gizi geriatri berbeda dengan kebutuhan gizi orang dewasa karena pengaruh faktor usia, lingkungan, penurunan aktivitas fisik serta perubahan fisiologis tubuh akibat penuaan. Lansia membutuhkan porsi makanan yang lebih sedikit dibandingkan dengan orang dewasa, tetapi frekuensi makan diberikan lebih sering (Fatmah, 2010).

RSUP dr. Soeradji Tirtonegoro Klaten memiliki visi "Menjadi Rumah Sakit Rujukan Nasional yang Ramah Lansia pada Tahun 2019". Berdasarkan hasil survei pendahuluan, jumlah pasien geriatri pada bulan Oktober 2018 mencapai 357 pasien $(24,17 \%)$ dari total pasien rawat inap sejumlah 1147 pasien. Diantara pasien tersebut, sebanyak 39 pasien geriatri kelas III mendapat makanan non diet, karena Instalasi Gizi RSUP dr. Soeradji Tirtonegoro Klaten belum memiliki standar makanan non diet yang khusus diperuntukkan bagi pasien geriatri. Dalam Pedoman Penyelenggaraan Makanan Rumah Sakit (PPMRS) RSUP dr. Soeradji Tirtonegoro Klaten, standar makanan non diet bagi pasien geriatri masih belum dibedakan dari standar makanan pasien bagi pasien dewasa. 
Standar makanan rumah sakit dibedakan menjadi standar makanan non diet dan standar makanan diet khusus. Makanan non diet diberikan pada pasien yang tidak memerlukan makanan khusus/diet berdasarkan penyakitnya (Almatsier, 2010). Di RSUP dr. Soeradji Tirtonegoro Klaten standar makanan non diet bagi pasien kelas III memiliki pola 3 kali makan utama dan 1 kali makan selingan, sehingga frekuensi makan lebih jarang dibandingkan dengan standar makanan pasien kelas II hingga VIP, yang sudah ada standar makanan diet dengan pola 3 kali makan utama dan 2 kali makan selingan.

Pemberian standar makanan yang tidak sesuai dengan kondisi dan kebutuhan pasien geriatri berdampak pada tingginya sisa makanan. Sisa makanan pasien merupakan salah satu indikator mutu pelayanan gizi. Berdasarkan Keputusan Menteri Kesehatan

No.129/Menkes/SK/II/2008 tentang Standar Pelayanan Minimal Rumah Sakit (SPM), sisa makanan yang tidak termakan oleh pasien maksimal sebanyak 20\%. Data sisa makanan bulan Oktober 2018 di RSUP dr.
Soeradji Tirtonegoro Klaten menunjukkan bahwa sisa makanan pasien yang tertinggi adalah sisa makanan pokok sebesar 13,95\% sedangkan sisa lauk hewani $9,17 \%$; lauk nabati $11,31 \%$; sayur $6,40 \%$ dan buah $2,40 \%$.

Makanan pasien yang tersisa berkaitan erat dengan pemakaian biaya makanan untuk pasien. Semakin banyak makanan yang tersisa mengakibatkan banyak biaya makanan yang terbuang, yang pada akhirnya berdampak pada pengelolaan biaya makanan pasien kurang efisien (Mas'ud et al., 2015). Penelitian Umihani dan Pramono (2015) menunjukkan bahwa biaya yang hilang dari sisa makanan pasien di RSUD dr. Adhyatma MPH sebesar Rp1.855.845, atau 35\% biaya dari total biaya makan. Sementara itu, penelitian Djamaluddin et al. (2005) di RSUP dr. Sardjito menyatakan bahwa biaya yang terbuang dari sisa makanan per hari mencapai Rp 1265,08 atau $10,79 \%$ dari total biaya makan harian. Penelitian yang dilakukan oleh Irawati et al. (2010) di RSJ Madani Palu dengan pasien skizofrenia diketahui rata-rata biaya sisa makanan yang terbuang sebesar 
Rp 1.529,33 atau 9,97\% dari total biaya makan. Salah satu strategi untuk mengurangi hilangnya biaya makan pasien di rumah sakit adalah berfokus pada kontrol porsi dan peningkatan mutu makanan (Williams dan Walton, 2011).

Berdasarkan uraian diatas, diperlukan adanya modifikasi standar makanan non diet dalam bentuk pengaturan besar porsi dan frekuensi makan yang dapat diterima oleh pasien geriatri, sehingga dapat meminimalkan biaya makan yang terbuang. Penelitian ini bertujuan untuk mengetahui pengaruh modifikasi standar makanan non diet terhadap biaya makan yang terbuang pada pasien geriatri kelas III di RSUP dr. Soeradji Tirtonegoro Klaten.

\section{METODE}

Desain penelitian yang digunakan adalah studi eksperimental dengan post test only with control group design. Penelitian dilaksanakan di RSUP dr. Soeradji Tirtonegoro Klaten pada bulan April 2019.

Populasi dalam penelitian ini adalah pasien geriatri yang dirawat di ruang rawat inap kelas III RSUP dr. Soeradji Tirtonegoro Klaten. Jumlah sampel yang diambil menggunakan metode total sampling yaitu jumlah total populasi pasien geriatri kelas III dalam periode satu bulan pada bulan penelitian sejumlah 34 orang. Sampel dibagi menjadi 2 kelompok yaitu kelompok perlakuan yang mendapat modifikasi standar makanan dan kelompok kontrol yang mendapat makanan sesuai standar rumah sakit. Modifikasi standar makanan dilakukan dengan modifikasi besar porsi makanan pokok setiap kali waktu makan utama dan modifikasi frekuensi makan menjadi tiga kali makan utama dan dua kali selingan. Masing-masing kelompok diamati sisa makanannya selama 2 hari menggunakan metode taksiran visual Comstock dengan enam skala (tidak ada sisa makanan (sisa $0 \%$ ), sisa $25 \%$, sisa $50 \%$, sisa $75 \%$, sisa $95 \%$ makanan tidak dikonsumsi sama sekali (sisa 100\%)). Biaya makan yang terbuang dihitung dengan mengalikan persentase sisa makanan per item menu dengan harga makanan dalam satuan rupiah ( $R p)$.

Instrumen yang digunakan dalam penelitian ini adalah timbangan digital untuk perlakuan modifikasi besar porsi dan formulir taksiran 
visual Comstock untuk pengambilan data sisa makanan. Data primer yang diambil meliputi data sisa makanan pasien dan data biaya makan yang terbuang. Data sekunder yang diambil meliputi data jumlah pasien geriatri berdasarkan kelas perawatan, data standar makanan biasa dan makanan lunak kelas III, data siklus menu, dan biaya makan yang diperoleh dari Instalasi Gizi RSUP dr Soeradji Tirtonegoro Klaten.

Data karakteristik responden, nilai gizi standar makanan biasa dan makanan lunak yaitu kandungan energi, protein, lemak dan karbohidrat, biaya makan (food cost), distribusi sisa makanan pasien dan biaya makan yang terbuang disajikan dalam bentuk tabel distribusi frekuensi. Untuk mengetahui pengaruh modifikasi standar makanan non diet terhadap biaya makan yang terbuang digunakan uji Mann Whitney dengan derajat kepercayaan $95 \%(\alpha=0,05)$.

\section{HASIL DAN PEMBAHASAN}

\section{Gambaran Modifikasi Standar}

\section{Makanan}

Penelitian ini membandingkan biaya makan yang terbuang pada kelompok perlakuan yang mendapat modifikasi standar makanan dan kelompok kontrol yang mendapat makanan sesuai standar rumah sakit. Modifikasi standar makanan dilakukan dengan modifikasi besar porsi makanan pokok setiap kali waktu makan utama dan modifikasi frekuensi makan menjadi tiga kali makan utama dan dua kali selingan. Besar porsi makanan pokok berupa nasi dimodifikasi dari berat awal 130 gram menjadi 100 gram, sedangkan bubur dimodifikasi dari berat awal 400 gram menjadi 300 gram.

Jenis makanan selingan yang ditambahkan sebagai modifikasi dalam selingan sore adalah biskuit sebanyak 30 gram. Pemilihan biskuit sebagai tambahan makanan selingan dikarenakan jenis makanan tersebut sesuai dengan pengadaan bahan makanan rumah sakit dengan harga paling rendah dan mudah didapatkan. Selain itu, biskuit termasuk kelompok jenis penukar bahan makanan pokok sehingga memiliki kandungan nilai gizi yang tidak jauh berbeda dengan beras sebagai makanan pokok yang dilakukan modifikasi porsi 
Tabel 1 Modifikasi Standar Makanan Non Diet Kelas III RSUP dr. Soeradji Tirtonegoro Klaten

\begin{tabular}{llcc}
\hline \multirow{2}{*}{ Waktu Makan } & \multicolumn{1}{c}{ Menu } & \multicolumn{2}{c}{ Besar Porsi (gram) } \\
\cline { 3 - 4 } Pagi & Makanan & Nasi $130 \mathrm{~g}$ & Nasi $100 \mathrm{~g}$ \\
& pokok & Bubur $400 \mathrm{~g}$ & Bubur $300 \mathrm{~g}$ \\
& Lauk hewani & 50 & 50 \\
& Lauk nabati & 50 & 50 \\
& Sayur & 75 & 75 \\
& Teh manis & $200 \mathrm{ml}$ & $200 \mathrm{ml}$ \\
\hline Selingan pagi & Susu & $200 \mathrm{ml}$ & $200 \mathrm{ml}$ \\
& Snack & 50 & 50 \\
\hline Siang & Makanan & Nasi $130 \mathrm{~g}$ & Nasi $100 \mathrm{~g}$ \\
& pokok & Bubur $400 \mathrm{~g}$ & Bubur $300 \mathrm{~g}$ \\
& Lauk hewani & 50 & 50 \\
& Lauk nabati & 50 & 50 \\
& Sayur & 75 & 75 \\
& Buah & 100 & 100 \\
\hline Selingan siang & Teh manis & $200 \mathrm{ml}$ & $200 \mathrm{ml}$ \\
& Snack & - & Biskuit $30 \mathrm{~g}$ \\
\hline Sore & Makanan & Nasi $130 \mathrm{~g}$ & Nasi $100 \mathrm{~g}$ \\
& pokok & Bubur $400 \mathrm{~g}$ & Bubur $300 \mathrm{~g}$ \\
& Lauk hewani & 50 & 50 \\
& Lauk nabati & 50 & 50 \\
& Sayur & 75 & 75 \\
\hline
\end{tabular}

Tabel 2. Distribusi Responden

\begin{tabular}{lcccccc}
\hline \multirow{2}{*}{ Karakteristik Respoden } & \multicolumn{2}{c}{ Perlakuan } & \multicolumn{2}{c}{ Kontrol } & \multicolumn{2}{c}{ Total } \\
\cline { 2 - 8 } & $\mathbf{n}$ & $\mathbf{\%}$ & $\mathbf{n}$ & $\mathbf{\%}$ & $\mathbf{n}$ & $\%$ \\
\hline 1. Kategori Usia & & & & & & \\
$\quad$ a. Lansia dini & 8 & 47,1 & 8 & 47,1 & 16 & 47,1 \\
b. Lansia berisiko & 9 & 52,9 & 9 & 52,9 & 18 & 52,9 \\
\hline$\quad$ Total & 17 & 100 & 17 & 100 & 34 & 100 \\
\hline 2. Jenis Kelamin & & & & & & \\
$\quad$ a. Laki-laki & 9 & 52,9 & 10 & 58,8 & 19 & 55,9 \\
b. Perempuan & 8 & 47,1 & 7 & 41,2 & 15 & 44,1 \\
\hline$\quad$ Total & 17 & 100 & 17 & 100 & 34 & 100 \\
\hline 3. Bentuk Makanan & & & & & & \\
a. Biasa (nasi) & 13 & 76,5 & 14 & 82,4 & 27 & 79,4 \\
b. Lunak (bubur) & 4 & 23,5 & 3 & 17,6 & 7 & 20,6 \\
\hline$\quad$ Total & 17 & 100 & 17 & 100 & 34 & 100 \\
\hline
\end{tabular}

\section{Karakteristik Responden}

Karakteristik responden dipaparkan pada Tabel 2, meliputi kategori usia, jenis kelamin dan bentuk makanan yang diberikan dari rumah sakit. Responden dengan kategori usia paling banyak adalah lansia berisiko (lebih dari 65 tahun) yaitu 18 orang 
$(52,9 \%)$. Jenis kelamin paling banyak adalah laki-laki yaitu 19 orang $(55,9 \%)$. Bentuk makanan yang paling banyak diterima adalah bentuk makanan biasa yaitu 27 orang $(79,4 \%)$.

\section{Gambaran Nilai Gizi Menu Makanan Non Diet}

terdapat

penurunan

kandungan zat gizi makro yaitu energi, protein, lemak dan karbohidrat pada menu makanan biasa yang dilakukan modifikasi standar makanan. Penurunan nilai gizi paling besar terdapat pada zat gizi karbohidrat menjadi sebesar $93,70 \%$. Terdapat pula perubahan kandungan zat gizi makro pada menu makanan lunak yang dilakukan modifikasi standar makanan. Peningkatan nilai gizi terdapat pada kandungan energi dan lemak. Sedangkan penurunan nilai gizi terdapat pada kandungan protein dan karbohidrat. Namun demikian, perubahan kandungan zat gizi pada menu makanan biasa maupun makanan lunak yang dilakukan modifikasi tidak melebihi $\pm 10 \%$.

Tabel 3. Nilai Gizi Menu

\begin{tabular}{llccc}
\hline Bentuk Makanan & \multicolumn{1}{c}{ Zat Gizi } & Standar RS & Modifikasi & \% \\
\hline Makanan biasa & Energi (kkal) & 2116 & 2091 & 98,82 \\
& Protein (g) & 72,9 & 71,9 & 98,63 \\
& Lemak (g) & 70,9 & 70,4 & 99,29 \\
& KH (g) & 309,6 & 290,4 & 93,70 \\
\hline Makanan lunak & Energi (kkal) & 1807 & 1810 & 100.17 \\
& Protein (g) & 69,4 & 68,9 & 99.28 \\
& Lemak (g) & 57,9 & 62,0 & 107,08 \\
& KH (g) & 264,0 & 253,9 & 96,17 \\
\hline
\end{tabular}

\section{Biaya Makan}

Terdapat peningkatan biaya makan pasien setelah dilakukan modifikasi standar makanan. Pada menu makanan biasa terdapat peningkatan biaya makan sebesar $105,41 \%$ dari biaya makan awal Rp 25.211,83 menjadi Rp 26.575,81, sedangkan pada menu makanan lunak terdapat peningkatan biaya makan
$105,59 \%$ dari biaya makan awal Rp 24.667,83 menjadi Rp 26.047,40. Peningkatan biaya makan tersebut berasal dari adanya modifikasi pengurangan porsi makanan pokok dan penambahan satu kali frekuensi snack yang memiliki nilai ekonomi lebih tinggi daripada makanan pokok. 


\section{Sisa Makanan Pasien}

Hasil analisis sisa makanan menunjukkan bahwa rata-rata sisa makanan pasien pada kelompok perlakuan sebesar 10,94\%, lebih kecil dibandingkan dengan rata-rata sisa makanan pasien pada kelompok kontrol sebesar 15,22\%. Angka sisa makanan tersebut masih memenuhi Standar Pelayanan Minimal (SPM) Rumah Sakit, bahwa sisa makanan yang tidak termakan oleh pasien sebanyak-banyaknya $20 \%$ (Kemenkes RI, 2008).

Tabel 4. Rata-rata Sisa Makanan Pasien

\begin{tabular}{lllccccc}
\hline \multirow{3}{*}{ Kelompok } & Pola Menu & \multicolumn{6}{c}{ Sisa Makanan Pasien (\%) } \\
\cline { 2 - 8 } Kontrol & Makanan & $\begin{array}{c}\text { Makan } \\
\text { Pagi }\end{array}$ & $\begin{array}{c}\text { Selingan } \\
\text { Pagi }\end{array}$ & $\begin{array}{c}\text { Makan } \\
\text { Siang }\end{array}$ & $\begin{array}{c}\text { Selingan } \\
\text { Siang }\end{array}$ & $\begin{array}{c}\text { Makan } \\
\text { Malam }\end{array}$ & $\begin{array}{c}\text { Rata- } \\
\text { rata }\end{array}$ \\
& pokok & 28,68 & - & 23,38 & - & 26,47 & 26,18 \\
& Lauk hewani & 14,56 & - & 7,35 & - & 11,18 & 11,03 \\
& Lauk nabati & 19,71 & - & 35,29 & - & 22,65 & 25,88 \\
& Sayur & 31,47 & - & 34,41 & - & 33,68 & 33,19 \\
& Buah & - & - & 4,41 & - & - & 4,41 \\
& Snack & - & 2,94 & - & - & - & 2,94 \\
& Minuman & 2,21 & 5,88 & - & 0,74 & - & 2,94 \\
\hline \multirow{6}{*}{ Perlakuanyyyyyyyyy} & Makanan & 21,03 & - & 19,12 & - & 16,03 & 18,73 \\
& pokok & & Rata-rata per hari & & 13.22 \\
\hline & Lauk hewani & 13,09 & - & 8,82 & - & 13,53 & 11,81 \\
& Lauk nabati & 9,41 & - & 13,09 & - & 15,15 & 12,55 \\
& Sayur & 21,18 & - & 22,65 & - & 23,24 & 22,35 \\
& Buah & - & - & 5,15 & - & - & 5,15 \\
& Snack & - & 3,68 & - & 4,41 & - & 4,04 \\
& Minuman & 0 & 5,88 & - & 0 & - & 1,96 \\
\hline
\end{tabular}

\section{Biaya Makan yang Terbuang}

Rata-rata biaya makan yang terbuang pada kelompok perlakuan sebesar Rp 2806,34 sedangkan pada kelompok kontrol sebesar Rp 3443,43 .

Tabel 5. Biaya Makan yang Terbuang

\begin{tabular}{llcccccr}
\hline \multirow{2}{*}{ Kelompok } & \multirow{2}{*}{ Pola Menu } & \multicolumn{7}{c}{$\begin{array}{c}\text { Makan } \\
\text { Pagi }\end{array}$} & $\begin{array}{c}\text { Selingan } \\
\text { Pagi }\end{array}$ & $\begin{array}{c}\text { Makan } \\
\text { Siang }\end{array}$ & $\begin{array}{c}\text { Selingan } \\
\text { Siang }\end{array}$ & $\begin{array}{c}\text { Makan } \\
\text { Malam }\end{array}$ & Jumlah \\
\hline \multirow{2}{*}{ Kontrol } & Makanan pokok & 215,61 & - & 180,10 & - & 204,44 & 600,15 \\
& Lauk hewani & 503,22 & - & 250,01 & - & 343,17 & $1.096,40$ \\
& Lauk nabati & 124,28 & - & 307,61 & - & 129,77 & 561,66 \\
& Sayur & 264,40 & - & 319,57 & - & 304,00 & 887,97 \\
& Buah & - & - & 29,12 & - & - & 29,12 \\
& Snack & - & 130,90 & - & - & - & 130,90 \\
& Minuman & 7,88 & 129,81 & - & 2,63 & - & 139,72 \\
\hline & \multicolumn{7}{c}{ Total } \\
\hline
\end{tabular}




\begin{tabular}{lllcccrc}
\hline \multirow{3}{*}{ Kelompok } & \multirow{2}{*}{ Pola Menu } & \multicolumn{7}{c}{ Biaya Makan yang Terbuang (Rp) } \\
\cline { 3 - 8 } & Makan & $\begin{array}{c}\text { Selingan } \\
\text { Pagi }\end{array}$ & $\begin{array}{c}\text { Makan } \\
\text { Siang }\end{array}$ & $\begin{array}{c}\text { Selingan } \\
\text { Siang }\end{array}$ & $\begin{array}{c}\text { Makan } \\
\text { Malam }\end{array}$ & Jumlah \\
\hline \multirow{4}{*}{ Perlakuan } & Makanan pokok & 122,50 & - & 117,43 & - & 95,03 & 344,95 \\
& Lauk hewani & 519,49 & - & 324,36 & - & 440,20 & $1.284,05$ \\
& Lauk nabati & 40,89 & - & 100,35 & - & 78,92 & 220,16 \\
& Sayur & 175,15 & - & 243,91 & - & 177,69 & 596,75 \\
& Buah & - & - & 64,85 & - & - & 64,85 \\
& Snack & - & 92,83 & - & 73,77 & - & 166,60 \\
& Minuman & 0 & 129,81 & - & 0 & - & 129,81 \\
\hline
\end{tabular}

Biaya makan yang terbuang dengan jumlah terbesar pada kedua kelompok terdapat pada menu lauk hewani. Sedangkan biaya makan yang terbuang dengan jumlah terkecil terdapat pada minuman. Menu lauk hewani memiliki biaya makan terbuang yang cukup tinggi walaupun angka sisa makanan cukup rendah disebabkan karena harga bahan utama lauk hewani memiliki nilai ekonomi yang lebih tinggi dibandingkan dengan harga bahan utama jenis menu yang lain sehingga jika dikonversikan terhadap angka sisa makanan akan menghasilkan sisa biaya makan yang tinggi pula.

Tabel 6. Distribusi Biaya Makan yang Terbuang pada Kelompok Perlakuan dan Kontrol

\begin{tabular}{lcccc}
\hline $\begin{array}{c}\text { Modifikasi Standar } \\
\text { Makanan }\end{array}$ & n & Median & Maks & Min \\
\hline Perlakuan & 17 & $1.350,58$ & $17.769,48$ & 202,50 \\
Kontrol & 17 & $2.523,99$ & $11.954,93$ & 545,88 \\
\hline
\end{tabular}

Berdasarkan hasil uji statistik didapatkan nilai p-value sebesar $0,109(\mathrm{p}>0,05)$ yang berarti tidak terdapat pengaruh yang signifikan modifikasi standar makanan non diet terhadap biaya makan yang terbuang pada pasien geriatri kelas III di RSUP dr. Soeradji Tirtonegoro Klaten.
Namun demikian, terdapat perbedaan rata-rata biaya makan yang terbuang pada kelompok perlakuan dan kontrol sebesar Rp 638,09 per hari.

Hasil tersebut sejalan dengan penelitian Taylor dan Barr (2006) tentang studi crossover yang membandingkan asupan energi pada 
lansia yang diberikan pola makan 3 kali sehari dengan pola makan 5 kali sehari berupa 3 kali makan utama dan 2 kali selingan. Hasil penelitian tersebut menyatakan bahwa pemberian makanan dengan porsi kecil dan sering tidak dapat meningkatkan asupan makan pada lansia dengan gangguan menelan.

Selain itu, terdapat tantangan pada pemberian makan dengan frekuensi yang lebih sering terutama peran keluarga maupun perawat dalam memberikan bantuan saat makan karena terdapat lansia yang tidak dapat makan secara mandiri (Dunne dan Dahl, 2007). Adanya dukungan dan motivasi dari orangorang sekitar terhadap responden juga dapat mempengaruhi semangat untuk menghabiskan makanan dan merasa dipedulikan oleh lingkungan sekitar.

Bentuk modifikasi kurang sesuai dengan kebiasaan pasien geriatri dapat menyebabkan tidak ada pengaruh modifikasi standar makanan non diet terhadap biaya makan yang terbuang pada pasien geriatri kelas III di RSUP dr. Soeradji Tirtonegoro Klaten. Terdapat lansia memiliki kecenderungan untuk melewatkan waktu makan berkaitan dengan kondisi fisik dan psikologis (Edfors dan Westergren, 2012), sehingga pemberian makan dengan frekuensi lebih sering mungkin tidak sesuai dengan kebiasaan makan responden. Bila kebiasaan makan pasien tidak sesuai dengan makanan yang disajikan baik dalam susunan menu maupun besar porsi, maka pasien cenderung tidak menghabiskan makanan dari rumah sakit (Puruhita et al., 2014).

Pemilihan jenis tambahan makanan selingan selain perlu mempertimbangkan aspek efisiensi biaya dengan memperhatikan harga makanan selingan yang dipilih serta kandungan nilai gizi yang sesuai standar, juga perlu memperhatikan aspek cita rasa, tekstur dan variasi makanan selingan sehingga dapat diterima oleh pasien geriatri. Namun, pada penelitian ini tidak dilakukan survei pendahuluan dalam menentukan modifikasi makanan selingan.Tidak adanya pengaruh modifikasi standar makanan non diet terhadap biaya makan yang terbuang pada pasien geriatri kelas III di RSUP dr. Soeradji Tirtonegoro Klaten juga dapat disebabkan oleh berbagai faktor selain modifikasi standar makanan. 
Sisa makanan tergantung dari daya terima pasien terhadap makanan, yang dipengaruhi oleh faktor internal (dari pasien terkait keadaan penyakitnya) dan faktor eksternal (dari makanan dan kepuasan pasien terhadap makanan) (Umihani dan Pramono, 2015).

Faktor internal pasien yang dapat mempengaruhi daya terima mencakup keadaan klinis dan patologis pasien seperti perubahan nafsu makan, perubahan indra pengecap, gangguan menelan (disfagia), stress dan lamanya dirawat (Kemenkes RI, 2013). Penelitian Simzari et al. (2017) menyatakan bahwa faktor utama yang menyebabkan penurunan asupan makan dan tingginya sisa makanan pasien adalah rasa mual, mulut kering dan hilangnya nafsu makan. Tingkat keparahan penyakit dan rasa nyeri yang dialami pasien juga dapat mempengaruhi sisa makanan pasien (Tanuwijaya et al., 2018). Faktor psikologis yaitu stress dan depresi yang kerap kali dialami lansia juga memiliki hubungan dengan sisa makanan yang berasosisi dengan penurunan asupan makan (Habiba dan Adriani, 2017). Faktor-faktor internal tersebut dapat berbeda pada masing-masing individu sehingga dapat menyebabkan daya terima dan sisa makanan yang bervariasi antar individu.

Yang dimaksud faktor eksternal pasien, mencakup mutu makanan (seperti rasa, aroma, besar porsi dan variasi menu, tekstur), sikap petugas, kesalahan pengiriman makanan, ketidak tepatan waktu makan atau jadwal makan, dan suasana tempat perawatan (Kemenkes RI, 2013). Penelitian Williams dan Walton (2011) menyatakan bahwa faktor mutu makanan yang meliputi rasa, terkstur dan penampilan makanan serta faktor pelayanan makan seperti sikap petugas penyaji makanan, kesalahan pemberian makanan dan ketidaktepatan jadwal makan menjadi penyebab tingginya sisa makanan pasien di rumah sakit. Manipulasi faktor suasana tempat perawatan, seperti jumlah orang di ruangan, warna, pencahayaan atau kebisingan juga dapat memberikan perubahan asupan makanan (Díaz and García, 2013). Penghematan biaya makan yang terbuang tidak hanya dapat dilakukan melalui upaya 
meminimalkan sisa makanan pasien, tetapi dapat dilakukan dengan strategi lain yaitu dengan pengawasan kegiatan penyelenggaraan makanan secara keseluruhan mulai dari kontrol perencanaan anggaran, pengadaan bahan makanan, penerimaan bahan makanan, penyimpanan dan inventaris bahan makanan hingga kegiatan pengolahan makanan (Neriz et al., 2014). Tidak ada strategi tunggal yang dapat menyelesaikan masalah terbuangnya biaya makanan berlebih di rumah sakit, sehingga diperlukan evaluasi dari berbagai pendekatan yang berpotensi efektif yang dapat memberikan pendekatan terstruktur pada proses peningkatan kualitas makanan dengan cara yang hemat biaya.

\section{KESIMPULAN DAN SARAN}

Dalam penelitian ini dapat disimpulkan bahwa tidak ada pengaruh modifikasi standar makanan non diet terhadap biaya makan yang terbuang pada pasien geriatri kelas III di RSUP dr. Soeradji Tirtonegoro Klaten. Rata-rata sisa makanan pasien pada kelompok perlakuan sebesar $10,94 \%$, lebih kecil dibandingkan dengan rata-rata sisa makanan pasien pada kelompok kontrol sebesar 15,22\%. Terdapat peningkatan biaya makan menjadi $105,41 \%$ pada menu makanan biasa dan $105,59 \%$ pada menu makanan lunak, setelah dilakukan modifikasi. Rata-rata biaya makan yang terbuang pada kelompok perlakuan sebesar Rp 2.806,34 sedangkan pada kelompok kontrol sebesar Rp 3.443,43.

$$
\text { Berdasarkan kesimpulan }
$$

tersebut maka disarankan kepada institusi penyelenggaraan makanan diharapkan dapat melakukan evaluasi menu dan standar makanan rumah sakit secara berkala guna meminimalkan sisa makanan pasien dan biaya makan yang terbuang. Selain itu perlu dilakukan penelitian lebih lanjut mengenai pengaruh bentuk-bentuk intervensi lain seperti modifikasi menu yang dapat dilakukan untuk mengurangi biaya makan yang terbuang dengan melakukan kontrol terhadap variabelvariabel pengganggu yang berasal dari faktor internal pasien. 


\section{DAFTAR PUSTAKA}

Almatsier, S. 2010, Penuntun Diet, Gramedia Pustaka Utama, Jakarta.

Djamaluddin, M., dan Prawirohartono, E. P. 2005, 'Analisis Zat Gizi dan Biaya Sisa Makanan pada Pasien dengan Makanan Biasa' Jurnal Gizi Klinik Indonesia vol. 1, no. 3, pp 108-112.

Dunne, J. L. dan Dahl, W. J. 2007, ‘A Novel Solution is Needed to Correct Low Nutrient Intakes in Elderly', Nutrition Reviews, 65(3), pp. 135-138. doi: 10.1301/nr.2007.mar.135.

Edfors, E. dan Westergren, A. 2012, 'Home-Living Elderly People's Views on Food and Meals', Journal of Aging Research, 2012.

Fatmah 2010, Gizi Usia Lanjut, Penerbit Erlangga, Jakarta.

Habiba, R. A. dan Adriani, M. 2017, 'Hubungan Depresi, Asupan, dan Penampilan Makanan dengan Sisa Makan Pagi Pasien Rawat Inap (Studi di Rumah Sakit Islam Jemursari Surabaya)', Amerta Nutr, pp. 198-208.

Irawati, Prawiningdyah, Y., dan Budiningsari, R. D. 2010, Analisis Sisa Makanan dan Biaya Sisa Makanan Pasien Skizofrenia Rawat Inap di Rumah Sakit Jiwa Madani Palu', Jurnal Gizi Klinik Indonesia vol. 6, no. 3, pp 123-131.

Kemenkes RI 2008, Keputusan Menteri Kesehatan No.129/Menkes/SK/II/2008 tentang Standar Pelayanan Minimal Rumah Sakit (SPM), Kementerian Kesehatan Republik Indonesia, Jakarta

Kemenkes RI 2013, Pedoman Pelayanan Gizi Rumah Sakit, Kementerian Kesehatan Republik Indonesia, Jakarta.

Lugito, P. N. H., Soejono, C. H., Wahyudi, E. R., dan Dewiasty, E. 2015, 'Pengaruh Status Nutrisi terhadap Kesintasan 30 Hari Pasien Geriatri yang Dirawat di Rumah Sakit', Jurnal Penyakit Dalam Indonesia, 2(3), pp. 8-17.

Mas'ud, H., Rochimiwati, S. N. dan Rowa, S. S. 2015, 'Studi Evaluasi Sisa Makanan Pasien dan Biaya Makanan Pasien di RSK dr Tadjuddin Chalid dan RSUD Kota Makassar', Media Gizi Pangan, XIX(1), pp. 91-95.

Morley, J. E. 2012, 'Undernutrition in older adults', Family Practice-The International Journal for Research in Primary Care, 8. doi: 10.1093/fampra/cmr054.

Neriz, L., Nunez, A. dan Ramis, F. 2014, 'A cost management model for hospital food and nutrition in a public hospital', BMC Health Serv Res 14:542.

PERGEMI 2017, Apa Itu Geriatri, diakses tanggal 15 November 2018, http://geriatrilansia.com.

Puruhita, N., Hagnyonowati, Adianto, S., Murbawani, E. A., dan Ardiana, M. 2014, 'Gambaran Sisa Makanan dan Mutu Makanan yang Disediakan 
Instalasi Gizi Rumah Sakit Umum Pusat dr. Kariadi Semarang', JNH, 2(3).

Simzari, K., Vahabzadeh, D., Saeidlou, S. N., Khoshbin, S. dan Bektas, Y. 2017, 'Food intake, plate waste and its association with malnutrition in hospitalized patients', Nutricion Hospitalaria, 34.

Tanuwijaya, L. K., Sembiring, L. G., Dini, C. Y., Arviani, E. P., dan Wani, Y. A. 2018, 'Sisa Makanan Pasien Rawat Inap: Analisis Kualitatif', Indonesian Journal of Human Nutrition, 5(1), pp. 51-61.

Taylor, K. A. dan Barr, S. I. (2006) 'Provision of Small, Frequent Meals Does Not Improve Energy Intake of Elderly Residents with Dysphagia Who Live in an Extended-
Care Facility', Journal of The Academy of Nutritions and Dietetics, 106(7), pp. 11151118.

Umihani, A. dan Pramono, A. 2015, 'Analisis Biaya yang HIlang dari Sisa Makanan Pasien di RSUD dr. Adhyatma MPH', Journal of Nutrition College vol. 4 no. 1, pp 18-23.

Wellman, N. S. dan Kamp, B. J. 2017, 'Nutrition in Aging', dalam Mahan, L. K. and Raymond, J. L. (eds) Krause's Food and The Nutrition Care Process. $14^{\text {th }}$ edn. Elsevier, Missouri, pp. 367-381.

Williams, P. dan Walton, K. 2011, 'Plate waste in hospitals and strategies for change', European e-Journal of Clinical Nutrition and Metabolism vol 6. 